\title{
AMMONIUM CHLORIDE AS NITROGEN SOURCE IN SUGARCANE HARVESTED WITHOUT BURNING ${ }^{(1)}$
}

\author{
Michele Xavier Vieira ${ }^{(2)}$, Paulo Cesar Ocheuze Trivelin ${ }^{(3)}$, \\ Henrique Coutinho Junqueira Franco ${ }^{(4)}$, Rafael Otto ${ }^{(2)}$ \& Carlos \\ Eduardo Faroni ${ }^{(5)}$
}

\section{SUMMARY}

The great difficulty of incorporation of $\mathrm{N}$ fertilizers into the "green sugarcane" system causes concern and since urea is the most commonly used source, there is the risk of loosing $\mathrm{NH}_{3}$ through volatilization. For this reason, a field experiment was undertaken (in a Hapludox Typic) with the objective of evaluating the agronomic efficiency of ammonium chloride on stubble of the second ratoon (SP89 1115), as well as its residual effect on the subsequent cycle (third ratoon). The experimental design was randomized blocks with four replications. Treatments consisted of three $N$ rates $\left(60,120\right.$ and $\left.180 \mathrm{~kg} \mathrm{ha}^{-1} \mathrm{~N}\right)$ in the form of $\mathrm{NH}_{4} \mathrm{Cl}$, in addition to a control treatment without the addition of $\mathrm{N}$ fertilizer. The ratoon cane of the second cutting was harvested in November 2006 and the treatments were applied in December 2006. The second ratoon was harvested mechanically in November 2007 and in December 2007, $450 \mathrm{~kg} \mathrm{ha}^{-1}$ of the NPK mixture 20-05-19 was applied, providing 90,22 and $86 \mathrm{~kg} \mathrm{ha}^{-1} \mathrm{~N}, \mathrm{P}_{2} \mathrm{O}_{5}$ and $\mathrm{K}_{2} \mathrm{O}$, respectively, for the purpose of evaluating the effect of residual-N from the treatments implanted in December 2006. An increase in the rates of $\mathrm{N}-\mathrm{NH}_{4} \mathrm{Cl}$ had a positive effect on the leaf concentrations of P, Mg and S. Stalk yield (MSS $\mathrm{Mg} \mathrm{ha}^{-1}$ of sugarcane stalks) and sugar (MSH - $\mathrm{Mg} \mathrm{ha}^{-1}$ of sucrose) in the November 2006 harvest responded linearly to the increase of $\mathrm{N}$ doses in the form of $\mathrm{NH}_{4} \mathrm{Cl}$. In relation to the effect of residual-N in the 2007/2008 harvest, it was observed, in general, that the concentrations of macronutrients in the sugarcane leaf +1 were within the range considered adequate in the state of São Paulo, Brazil. The residual-N of the $\mathrm{NH}_{4} \mathrm{Cl}$ doses resulted in a significant reduction in stalk (MSS)

\footnotetext{
(1) Received for publication in May 2009 and approved in May 2010.

(2) Agronomist, doctoral candidate of Graduate Program in Soils and Plant Nutrition of Escola Superior de Agricultura "Luiz de Queiroz" - ESALQ/USP. Av. Pádua Dias 11, CP 9, Zip Code 13418-900 Piracicaba (SP), Brasil. FAPESP Scholarship holder. Emails: micheleagronomia@yahoo.com.br; rotto@esalq.usp.br

(3) Associate Professor, Stable Isotopes Laboratory, Center of Nuclear Energy in Agriculture (Centro de Energia Nuclear na Agricultura), CENA/USP (CNPq Scholarship holder). Av. Centenário 303, CP 96, Zip Code 13400-970 Piracicaba (SP), Brasil. E-mail: pcotrive@cena.usp.br

(4) Agronomist, Post-doctoral candidate of Stable Isotopes Laboratory, CENA/USP. E-mail: hjfranco@cena.usp.br

(5) Agronomist, Doctor in Soils and Plant Nutrition, researcher of Centro de Tecnologia Canavieira - CTC. Fazenda Santo Antônio, s/n, CP 162, Zip Code 13400-970 Piracicaba (SP), Brasil. E-mail: cfaroni@ctc.com.br
} 
and sugar (MSH) production. It may be concluded that the $\mathrm{NH}_{4} \mathrm{Cl}$ source at a dose of $120 \mathrm{~kg} \mathrm{ha}^{-1} \mathrm{~N}$ in ratoon fertilization of the second cutting was agronomically efficient, presenting, however, less efficiency of residual-N in the subsequent cycle.

Index terms: Saccharum spp, nitrogen fertilization, ratoon cane.

\title{
RESUMO: CLORETO DE AMÔNIO COMO FONTE DE NITROGÊNIO EM CANA-DE-AÇÚCAR COLHIDA SEMQUEIMA
}

\begin{abstract}
A maior dificuldade de incorporação dos fertilizantes nitrogenados no sistema de "canacrua" é preocupante e, uma vez que a ureia é a fonte mais usada, pode-se incorrer em riscos de perdas de $\mathrm{NH}_{3}$ por volatilização. Nesse sentido, foi realizado experimento em campo (Latossolo Vermelho-Escuro distrófico argiloso), com o objetivo de avaliar a eficiência agronômica do $\mathrm{NH}_{4} \mathrm{Cl}$ em soqueira de segunda rebrota (SP89 1115), bem como o seu efeito residual no ciclo subsequente (terceira rebrota). O delineamento experimental foi o de blocos casualizados, com quatro repetições. Os tratamentos constaram de três doses de $N\left(60,120\right.$ e $\left.180 \mathrm{~kg} \mathrm{ha}^{-1} \mathrm{~N}\right) \mathrm{na}$ forma de $\mathrm{NH}_{4} \mathrm{Cl}$, além do tratamento testemunha sem adição de $\mathrm{N}$-fertilizante. A cana soca de segundo corte foi colhida em novembro de 2006 e, em dezembro de 2006, foram aplicados os tratamentos. A colheita mecanizada da segunda rebrota foi realizada em novembro de 2007 e, em dezembro de 2007, foram aplicados $450 \mathrm{~kg} \mathrm{ha}^{-1}$ do formulado 20-05-19, fornecendo 90, 22 e $86 \mathrm{~kg} \mathrm{ha} \mathrm{s}^{-1}$ de $\mathrm{N}, \mathrm{P}_{2} \mathrm{O}_{5}$ e $\mathrm{K}_{2} \mathrm{O}$, respectivamente, visando avaliar o efeito do $\mathrm{N}$-residual dos tratamentos implantados em dezembro de 2006. O aumento nas doses de $\mathrm{N}$ - $\mathrm{NH}_{4} \mathrm{Cl}$ promoveu efeito positivo nas concentrações foliares de P, Mg e S. A produtividade de colmos por hectare (TCH) e açúcar (TPH) na colheita de novembro de 2006 respondeu de forma linear ao incremento das doses de $\mathrm{N}$ na forma de $\mathrm{NH}_{4} \mathrm{Cl}$. Com relação ao efeito do $\mathrm{N}$-residual na safra 2007/2008, verificou-se, em geral, que as concentrações de macronutrientes na folha +1 de cana-de-açúcar estavam dentro da faixa considerada adequada para o Estado de São Paulo, Brasil. $\mathrm{O} \mathrm{N}$-residual das doses de $\mathrm{NH}_{4} \mathrm{Cl}$ resultou em significativa redução na produção de colmos (TCH) e açúcar (TPH). Concluiu-se que a fonte $\mathrm{NH}_{4} \mathrm{Cl}$ na dose de $120 \mathrm{~kg} \mathrm{ha}^{-1} \mathrm{de} \mathrm{N}$, em adubação de soqueira de segundo corte, mostrou-se agronomicamente eficiente, apresentando, porém, menor eficiência do $N$-residual no ciclo subsequente.
\end{abstract}

Termos de indexação: Saccharum spp., adubação nitrogenada, cana soca.

\section{INTRODUCTION}

The changes in the sugarcane harvesting system, from the former straw removal by burning to mechanically harvested "green cane", are an irreversible process foreseen in the legislation of the sugar-alcohol sector. These changes represent advantages with regard to soil conservation, moisture retention and nutrient recycling, among others. Nevertheless, the difficulty of fertilization is increased, due to the need of incorporating the fertilizers during cultivation, especially in the case of sugarcane harvested mechanically without straw removal (burning), where a significant quantity of residues (10 to $30 \mathrm{Mg} \mathrm{ha}^{-1}$ ) is left on the soil surface (Franco et al., 2007).

This difficulty causes concern, bearing in mind that urea is the fertilizer used in greatest quantity for being inexpensive, increasing the risks of $\mathrm{N}-\mathrm{NH}_{3}$ losses through volatilization when applied to straw- covered soil surfaces. Upon contact with urease present in soil and plant residues, urea undergoes hydrolysis, producing ammonium carbonate $\left[\left(\mathrm{NH}_{4}\right)_{2} \mathrm{CO}_{3}\right]$, which raises the $\mathrm{pH}$, resulting in the emission of ammonia gas $\left(\mathrm{NH}_{3}\right)$ to the atmosphere (Costa, 2003). Thus, the presence of straw covering the soil modifies the agrisystem, requiring a reformulation of the $\mathrm{N}$ fertilization management.

Fertilizers and agricultural chemicals are mainly responsible for the high production costs in the sugaralcohol sector as well as in the case of other crops. Currently, the country already imports $64 \%$ of the N fertilizer demand (ANDA, 2009) and with the consumption increase, the degree of dependency on the imported product will become even more critical. Ammonium chloride a byproduct of soda ash (sodium carbonate $-\mathrm{Na}_{2} \mathrm{CO}_{3}$ ) production, is indicated as an alternative $\mathrm{N}$ source for sugarcane, since it contains $25-26$ and $66 \%$ of the $\mathrm{N}$ and chlorine nutrients, respectively. Research results showed good efficiency 
of ammonium chloride in rice production abroad and the compound is therefore widely used as rice $\mathrm{N}$ fertilizer in Japan and India (Tisdale et al., 1985; Ashraf et al., 2005).

Due to the difficulties of $\mathrm{N}$ fertilizer management on green cane, studies rarely report the use of more than $40 \%$ of fertilizer $\mathrm{N}$ by sugarcane (Trivelin et al., 2002). This low recovery is partly attributed to the residual effect in the soil due to the high $\mathrm{N}$ fertilizer immobilization, and to $\mathrm{N}$ losses in the soilplant-atmosphere system. As pointed out, it is of fundamental importance to find alternative $\mathrm{N}$ fertilizers for a stabilization of the green cane system, as well as more adequate $\mathrm{N}$ fertilizer rates for the crop, which can be recommended with a view to yield increases without causing environmental damage, while increasing the longevity of the sugarcane fields.

Since sugarcane is exploited in various growth cycles before replanting, it is considered a semiperennial crop. In this respect, the benefits of $\mathrm{N}$ fertilization throughout the years or in successive harvests must be considered. For example, Vitti et al. (2007) reported a linear response to $\mathrm{N}$ rates in stalk production in the second ratoon. This response extended to the third ratoon, even with the application of a single dose of $\mathrm{N}\left(100 \mathrm{~kg} \mathrm{ha}^{-1}\right)$.

In this context, the objective of the present study was to evaluate the agronomic efficiency of ammonium chloride as alternative $\mathrm{N}$ fertilizer for sugarcane, as well as the residual $\mathrm{N}$ effect from this source on the agriculture cycle following application.

\section{MATERIAL AND METHODS}

The experiment was developed under field conditions in a commercial sugarcane field in Piracicaba county, São Paulo, Brazil, in the experimental area Fazenda Primavera (latitude South $22^{\circ} 42^{\prime} 04$ ", longitude West $47^{\circ} 33^{\prime} 29$ ", altitude $560 \mathrm{~m}$ asl). The sugarcane cultivar used was SP89 1115 (second ratoon) and the soil classified as a Typic Hapludox, with the following chemical properties in the arable layer $(0-25 \mathrm{~cm}): \mathrm{pH}\left(\mathrm{CaCl}_{2}\right)=4.4 ; \mathrm{SOM}$ $\left(\mathrm{g} \mathrm{dm}^{-3}\right)=32.3 ; \mathrm{P}$ resin $\left(\mathrm{mg} \mathrm{dm}{ }^{-3}\right)=11.7 ; \mathrm{S}_{-} \mathrm{SO}_{4}$ $\left.(\mathrm{mg} \mathrm{dm})^{-3}\right)=50.3 ; \mathrm{K}\left(\mathrm{mmol}_{\mathrm{c}} \mathrm{dm}^{-3}\right)=1.8 ; \mathrm{Ca}\left(\mathrm{mmol}_{\mathrm{c}} \mathrm{dm}^{-3}\right)=$ 20; $\mathrm{Mg}\left(\mathrm{mmol}_{\mathrm{c}} \mathrm{dm}^{-3}\right)=9.7 ; \mathrm{H}+\mathrm{Al}\left(\mathrm{mmol}_{\mathrm{c}} \mathrm{dm}^{-3}\right)=69$; $\mathrm{Al}\left(\mathrm{mmol}_{\mathrm{c}} \mathrm{dm}^{-3}\right)=5 ; \mathrm{SB}\left(\mathrm{mmol}_{\mathrm{c}} \mathrm{dm}^{-3}\right)=31.5 ; \mathrm{CEC}$ $\left(\mathrm{mmol}_{\mathrm{c}} \mathrm{dm}^{-3}\right)=101$ and $\mathrm{V} \%=31$.

The experimental design was randomized blocks with four replications, consisting of three $\mathrm{N}$ rates $(60$, 120 and $180 \mathrm{~kg} \mathrm{ha}^{-1}$ ) in the form of ammonium chloride, as well as a control treatment without fertilizer- $\mathrm{N}$ application. The area of each experimental plot was $135 \mathrm{~m}^{2}$, with seven rows, $15 \mathrm{~m}$ long, spaced $1.5 \mathrm{~m}$ apart.
Mineral fertilization of the second sugarcane ratoon on December 14, 2006, was applied as ammonium chloride $\left(\mathrm{NH}_{4} \mathrm{Cl}\right)$ over the straw and along the row of the sugarcane ratoon (at a distance of $0.25 \mathrm{~m}$ from the center of the sugarcane row). In all treatments, $180 \mathrm{~kg} \mathrm{ha}^{-1} \mathrm{~K}_{2} \mathrm{O}$ was applied in the form of potassium chloride.

For an evaluation of the nutritional status of the plants during the ratoon cane cycle, 60 days after fertilization (d.a.f.), the leaves were sampled according to the Kuijper system (sampling of leaf $+1, \mathrm{~L}+1$ ). From the plant top downwards, $\mathrm{L}+1$ is the first leaf with a visible point of separation between the leaf blade and sheath called "dewlap", also called the TVD ("Top Visible Dewlap"). The middle $20 \mathrm{~cm}$ of five L +1 per plot were sampled, randomly harvested, in the three central rows of the plot, removing the midribs. These samples were dried in a forced air circulation oven at $65^{\circ} \mathrm{C}$. After drying they were ground in a Wiley type laboratory mill and analyzed for the macronutrient concentrations (N, P, K, Ca, Mg, and $\mathrm{S}$ ), according to Malavolta et al., 1997.

The sugarcane yield was evaluated four times during ratoon growth, sampled 0, 60, 120 and 180 days after fertilization (d.a.f.). In these evaluations, the entire plant matter of the shoots of the plants in $2 \mathrm{~m}$ of a row, one sample per plot, was collected and quantified directly in the field. At this time, the number of tillers of these samples were counted (number of tillers per $2 \mathrm{~m}$ of a row).

In the first two time periods, the tillers were counted in $20 \mathrm{~m}$ of the ratoon row in each plot (two $10 \mathrm{~m}$ segments), to calculate the average number of stalks per meter in each experimental plot. In these evaluations, the weight of the plant matter of the shoots was determined in $\mathrm{Mg} \mathrm{ha}^{-1}$. In this calculation, the number of tillers of each sample collected in $2 \mathrm{~m}$, corrected by the number of plants resulting from the counting in $20 \mathrm{~m}$ of the ratoon row, was considered. This correction was necessary due to the variability in the number of tillers that normally occurs in a sugarcane field.

On November 21, 2007 (342 days after fertilization), the final stalk yield (MSS) was evaluated, collecting four central rows of $15 \mathrm{~m}$ per plot (60 $\mathrm{m}$ of furrow). These rows were mechanically harvested (CASE model A7700) without previous cane burning, and the yield was evaluated on a truck equipped with instruments containing a load cell.

After the sugarcane ratoon harvest (second regrowth), in November 2007, the soil was sampled for a chemical characterization of fertility at a depth of 0-25 cm, collecting compound soil samples in all plots of the experiment implanted in 2006. The samples were always collected on the same side of the sugarcane row at a distance of $25 \mathrm{~cm}$ from the center of the furrow. The soil chemical properties of the arable layer $(0-25 \mathrm{~cm})$ in the third ratoon cycle are shown in table 1. 
Table 1. Chemical characteristics of the soil $(0-25 \mathrm{~cm})$ in terms of doses of $\mathrm{N}-\mathrm{NH}_{4} \mathrm{Cl}$ after harvesting the second sugarcane ratoon in November 2007

\begin{tabular}{|c|c|c|c|c|c|c|c|c|c|c|c|}
\hline Dose N & SOM & $\mathrm{pH} \mathrm{CaCl}{ }_{2}$ & $\mathrm{~S}_{-} \mathrm{SO}_{4}$ & $\mathbf{P}$ & $\mathbf{K}$ & $\mathbf{C a}$ & Mg & $\mathrm{H}+\mathrm{Al}$ & $\mathrm{SB}$ & CEC & V \\
\hline $\mathrm{kg} \mathrm{ha}^{-1}$ & $\mathrm{~g} \mathrm{dm}^{-3}$ & & \multicolumn{2}{|c|}{$-\mathrm{mg} \mathrm{dm}^{3}-$} & \multicolumn{6}{|c|}{$-\mathrm{mmol}_{\mathrm{c}} \mathrm{dm}^{-3}$} & $\%$ \\
\hline 0 & 33.7 & 4.5 & 32.0 & 17.7 & 1.9 & 24.5 & 11.0 & 57.5 & 37.5 & 94.9 & 39.2 \\
\hline 60 & 36.2 & 4.5 & 23.2 & 21.2 & 2.2 & 23.5 & 9.7 & 65.5 & 35.4 & 100.9 & 35.0 \\
\hline 120 & 35.0 & 4.5 & 25.3 & 19.5 & 2.1 & 23.8 & 9.0 & 65.0 & 34.8 & 99.8 & 34.5 \\
\hline 180 & 32.5 & 4.3 & 27.2 & 21.2 & 1.9 & 17.7 & 6.2 & 69.0 & 25.9 & 94.9 & 28.0 \\
\hline
\end{tabular}

SOM: soil organic matter; SB: sum of bases; CEC: cation exchange capacity; BS: base saturation.

On December 17, 2007, the fourth agricultural cycle of the crop (third ratoon) was fertilized with $450 \mathrm{~kg} \mathrm{ha}^{-1}$ of 20-05-19 NPK fertilizer, providing 90, 22 and $86 \mathrm{~kg} \mathrm{ha}^{-1} \mathrm{~N}, \mathrm{P}_{2} \mathrm{O}_{5}$ and $\mathrm{K}_{2} \mathrm{O}$, respectively, according to the soil analysis and expected yield (Technical Bulletin 100). These rates were applied in all treatments, including the control, to evaluate the residual $\mathrm{N}$ effect on the soil-plant system. The fertilizer was applied in a band, over the straw, along-side the sugarcane ratoon row (at a distance of $25 \mathrm{~cm}$ from the center of the row).

In November 2008, 348 days after fertilization, the final stalk production (MSS) was evaluated, based on four central rows of $15 \mathrm{~m}$ per plot (60 m furrow). These rows were harvested mechanically (CASE model A7700) without previous burning of the sugarcane field, and the yield was evaluated on a truck equipped with instruments containing a load cell.

To calculate the agricultural contribution margin (ACM), data from the price of the TRS (total recoverable sugar), CLT (cutting, loading and transport) and the cost per ton of ammonium chloride were used, provided by the agricultural department of the Iracema Sugar Mill. The ACM was calculated according to the model of Fernandes (2003). The agricultural contribution margin (ACM) was used, because it is more easily executed and does not require data of the expected revenue from sugar and alcohol sale.
For the climatological water balance (Figure 1), data from crop evapotranspiration and rainfall data of the experimental area were used and calculated using electronic charts (Rolim et al., 1998).

The experimental data were subjected to analysis of variance (ANOVA) SAS (2004), using the F test at a $10 \%$ confidence interval. Thereafter, where variation was significant, the effect of the $\mathrm{N}$ rates from ammonium chloride was verified in regression analyses $(p<0.01)$.

\section{RESULTS AND DISCUSSION}

The number of tillers per meter 60 and 120 d.a.f. was influenced by the increase of $\mathrm{N}-\mathrm{NH}_{4} \mathrm{Cl}$, adjustable to the quadratic regression model (Figure 2). The dose of $\mathrm{N}-\mathrm{NH}_{4} \mathrm{Cl}$ that resulted in the maximum tillering of stalks 60 and 120 days after fertilization was $100 \mathrm{~kg} \mathrm{ha}^{-1} \mathrm{~N}$. At the highest dose of $\mathrm{N}-\mathrm{NH}_{4} \mathrm{Cl}$ $\left(180 \mathrm{~kg} \mathrm{ha}^{-1} \mathrm{~N}\right)$ the reduction in tillering may indicate toxicity of $\mathrm{Cl}$ (Figure 2), since the anion represents $66 \%$ of the fertilizer composition and the $\mathrm{N}$ only $25 \%$. According to Marschner (1995) high Cl concentrations in the soil can reduce the $\mathrm{N}$ plant uptake due to the antagonistic effect between $\mathrm{Cl}^{-}$and the $\mathrm{NO}_{3}{ }^{-}$, which may have influenced the tillering, affecting the yield of the subsequent cycle. In addition,
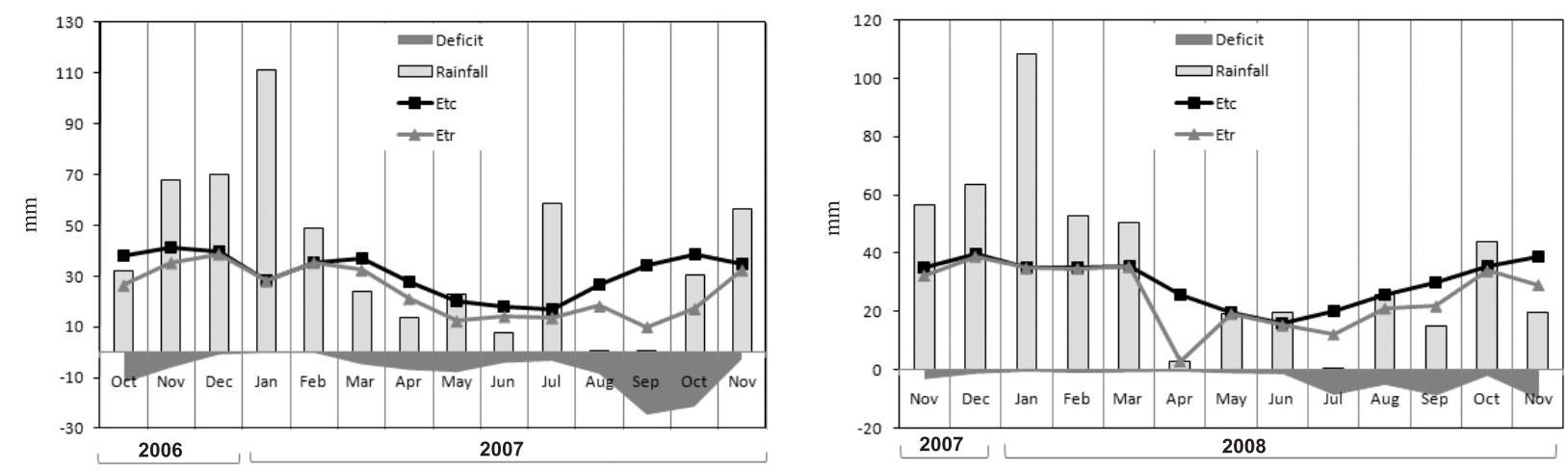

Figure 1. Climatological water balance of the experimental area in the agricultural cycle of the second and third ratoon of sugarcane. ETc: Potential evapotranspiration of the crop; ETr: Real evapotranspiration of the crop; Deficit.: Soil water deficit. 
diverse studies have shown the negative effect of the chloride ion which increases soil salinity, with an effect on important physiological processes of plant growth related to the osmotic effect, inducing water stress and a direct toxic effect, mainly on enzymatic and membrane systems of the plants (Bethke \& Drew, 1992; Yahya, 1998).

Maximum tillering of the second ratoon was observed 60 d.a.f. at the doses evaluated (Figure 2). This greater speed in reaching maximum tillering in ratoon cane can be explained by the pre-established root system of the varieties, while the root system of cane-plant must first be developed. For 90 days after sugarcane harvest, the root system formed in the cycle is responsible for water and nutrient uptake which is translocated to the buds from the base of the sugarcane ratoon. In addition, for ratoon sprouting, reserves in the rhizomes or underground stems that remain buried in the soil after cane harvest and roots from the previous cycle must be considered. The hypothesis of directing the plant reserves to the underground part (roots and rhizomes) and later use by the crop was shown by Trivelin et al. (1984). These authors reported that $7 \%$ of the $\mathrm{N}$ applied to sugarcane shoots was translocated to the root system and later used during sugarcane regrowth. Possibly, this nutrient translocation is a mechanism ensuring greater vigor of the root system and regrowth of a next cycle (Trivelin et al., 2002).

Besides, the climatic conditions favored ratoon sprouting by the combination of adequate water supply with high temperatures. The second ratoon harvest occurred at the end of October 2006 when the climatic conditions were totally favorable for the sprouting of the subsequent cycle. From this period until July 2007 , real crop evapotranspiration was very near the potential transpiration, due to the favorable conditions of temperature, solar radiation and water availability, allowing maximum plant growth (Figure 1).

For production of fresh shoot biomass (Figure 3), an influence of the $\mathrm{N}-\mathrm{NH}_{4} \mathrm{Cl}$ doses was observed only 120 d.a.f. The response equation of this variable to $\mathrm{N}$ application in the form of ammonium chloride showed that the dose of $117 \mathrm{~kg} \mathrm{ha}^{-1} \mathrm{~N}$ resulted in maximum production. These results also provide evidence of a possible toxicity effect of $\mathrm{Cl}$ at the highest dose, as discussed for the results of tillering. The correlation between tillering and fresh plant matter of the shoots 120 d.a.f. was high $(r=0.994)$ for the second ratoon $(\mathrm{p}<0.05)$.

With exception of $\mathrm{N}$ concentrations, the increase in the ammonium chloride doses generally affected the nutrient concentrations in the diagnostic leaves positively, which were within the range of sufficiency suggested for sugarcane in the state of São Paulo (N: 18.0-25.0; P: 1.5-3.0; K: 10.0-16.0; Ca: 2.0-8.0; Mg: 1.0-3.0; S: $1.5-3.0 \mathrm{~g} \mathrm{~kg}^{-1} \mathrm{DM}$ ) (Raij \& Cantarella, 1997).
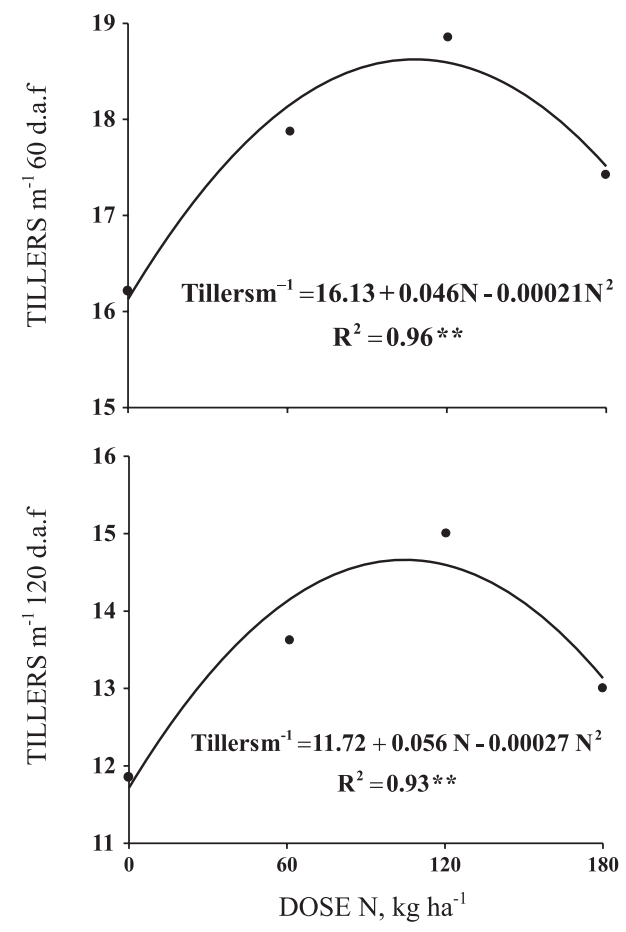

Figure 2. Number of tillers 60 and 120 days after fertilization in terms of the doses of $\mathrm{N}_{-} \mathrm{NH}_{4} \mathrm{Cl}$. **: significant at $5 \%$.

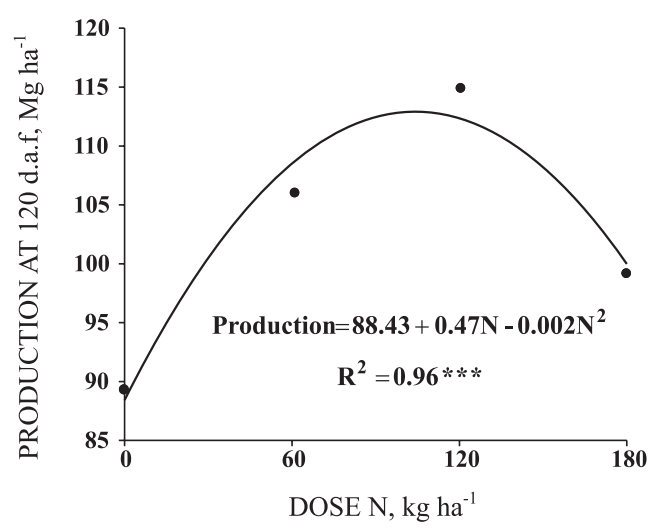

Figure 3. Production of fresh shoot biomass 120 days after fertilization in terms of the doses of $\mathrm{N}$ $\mathrm{NH}_{4} \mathrm{Cl}$. ***: significant at $1 \%$.

Nitrogen concentrations in the leaf +1 were 15.4 and $16.6 \mathrm{~g} \mathrm{~kg}^{-1}$ in the control treatment and $60 \mathrm{~kg} \mathrm{ha}^{-1} \mathrm{~N}$ respectively, values which are considered below the limit of sufficiency (18-25 $\left.\mathrm{g} \mathrm{kg}^{-1}\right)$. According to Marschner (1995), high Cl concentrations in the soil may decrease $\mathrm{NO}_{3}{ }^{-}$uptake by the plants due to the antagonistic effect which exists between them. Bar et al. (1991) affirmed that the $\mathrm{N}$ concentration in corn plants is affected by soil salinity, and $\mathrm{NO}_{3}{ }^{-}$uptake and transport are limited under saline conditions due to the antagonistic effect between nitrate and chloride ions. Nevertheless, it is important to highlight that 
$\mathrm{Cl}$ is necessary for the breakdown reactions of the water molecule in photosynthesis, producing $\mathrm{O}_{2}$ (Clarke \& Eaton-Ryne, 2000), which is also essential for cell division (Harling et al., 1997).

Phosphorus concentrations in $\mathrm{L}+1$ increased linearly with the increased $\mathrm{N}$ rates from the ammonium chloride source 60 d.a.f. (Figure 4a), while the production of fresh shoot biomass did not respond as much to the $\mathrm{N}$ rates as to the increase of the leaf $\mathrm{P}$ content at this same stage of development. A reduction in the shoot production was observed at the highest $\mathrm{N}$ dose 120 d.a.f. (Figure 2), possibly caused by the toxic effect of the $\mathrm{Cl}$. Although $\mathrm{P}$ is taken up by sugarcane in lower quantities than $\mathrm{N}$ and $\mathrm{K}$, this nutrient plays a key role in plant metabolism, particularly in protein formation and in the process of cell division and photosynthesis (Blair et al., 1971).

Concentrations of $\mathrm{K}$ in the $\mathrm{L}+10$ d.a.f. decreased linearly with the increasing $\mathrm{N}$ rates from the ammonium chloride source (Figure 4b); however, they were above the lower limit of the sufficiency range (10.0-16.0 $\left.\mathrm{g} \mathrm{kg}^{-1} \mathrm{DM}\right)$. According to Larcher (2000), the uptake of $\mathrm{NO}_{3}^{-}, \mathrm{K}$ and $\mathrm{Ca}$ is reduced when the $\mathrm{Cl}$ content in the soil is high. On the other hand, reduction in the $\mathrm{K}$ concentration under saline stress is an additional complication for plant growth since in some situations the nutrient is the main contributor to the decrease of the osmotic potential, a strategy necessary for water uptake in these circumstances (Jeschke et al., 1986; Marschner, 1995).
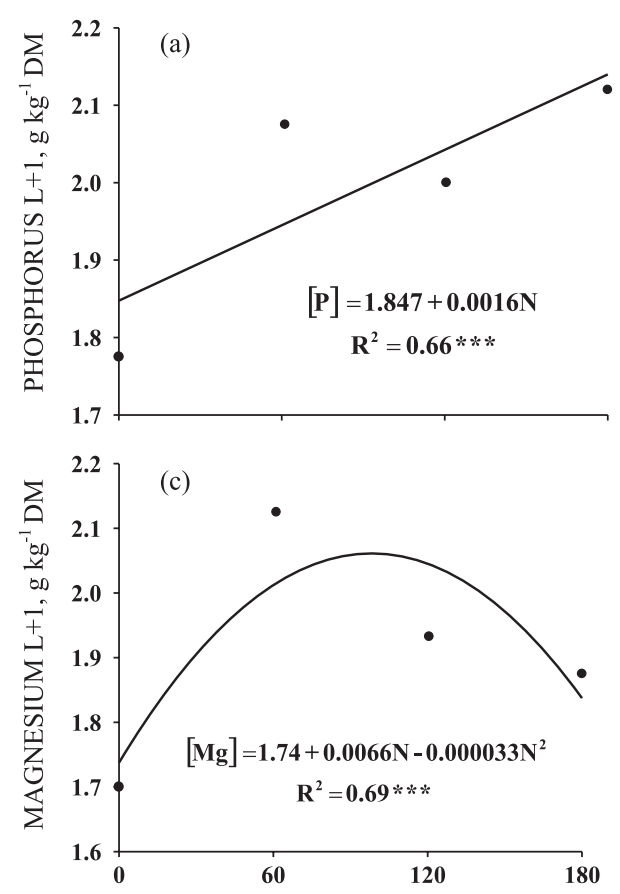

Thus, it is possible to suggest that the reduction in plant growth under high doses of $\mathrm{N}-\mathrm{NH}_{4} \mathrm{Cl}$ could be a reflection, at least in part, of the lower $\mathrm{K}$ concentration in plant tissues, since this element is extremely important for the osmotic adjustment of the plant, and necessary as well for the maintenance of the photosynthetic capacity due to its importance in protein synthesis and enzymatic activation (Taiz $\&$ Zeiger, 2004). In spite of not differing from each other, the Ca concentrations in all treatments were at the threshold of the sufficiency ranges $\left(2.0-8.0 \mathrm{~g} \mathrm{~kg}^{-1}\right.$ DM).

The effect of $\mathrm{N}$ rates on the $\mathrm{Mg}$ concentration was highly significant, represented by the quadratic regression model (Figure 4c). Nitrogen fertilization in general is associated with greater $\mathrm{Mg}$ uptake by the plants, due to the synergistic effect between the two nutrients $(\mathrm{N} \mathrm{x} \mathrm{Mg)}$. As the relationship of the leaf $\mathrm{Mg}$ concentrations with the $\mathrm{N}-\mathrm{NH}_{4} \mathrm{Cl}$ doses was quadratic, one may once more conclude that the $\mathrm{Cl}$ in the soil affect the $\mathrm{Mg}$ uptake, as mentioned for $\mathrm{NO}_{3}^{-}$, $\mathrm{K}$ and Ca by Larcher (2000).

The $\mathrm{S}$ concentrations in the sugarcane $\mathrm{L}+1$, evaluated 60 d.a.f. increased linearly with the increase

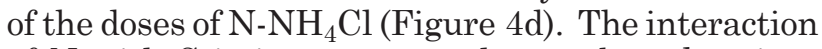
of $\mathrm{N}$ with $\mathrm{S}$ is important and must be taken into account in fertilization programs. According to Cantarella (2007), S deficiency often leads to a reduced utilization of $\mathrm{N}$ fertilizer. A deficiency of this nutrient results in reduced amino acid production and the proteins that contain the amino acids cannot be
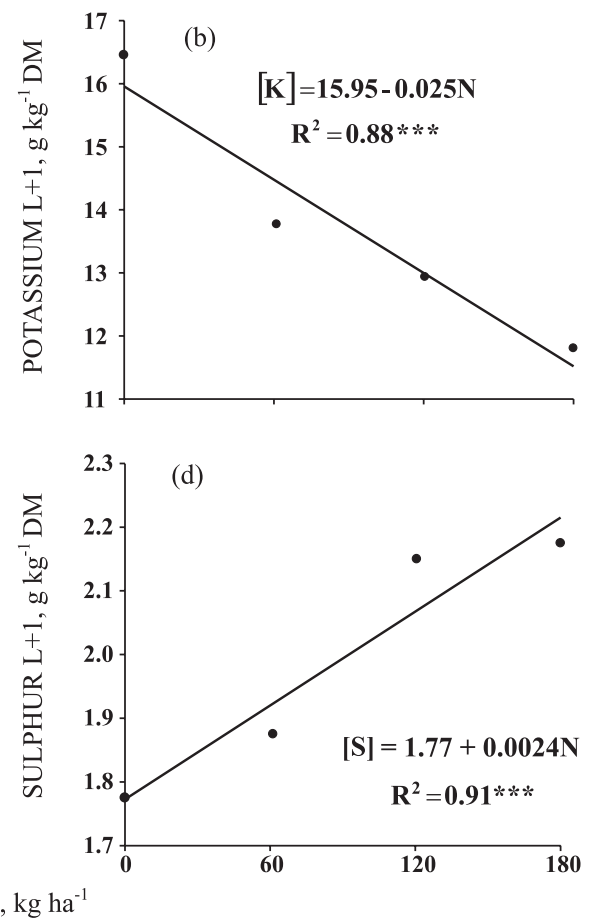

Figure 4. Macronutrient concentrations in leaf diagnosis in the second ratoon of sugarcane 60 d.a.f. in terms of the doses of $\mathrm{N}-\mathrm{NH}_{4} \mathrm{Cl}$ (sampling of leaf +1 ). *** significant at $1 \%$. 
formed. Thus, plants insufficiently supplied with $\mathrm{S}$ are not able to assimilate $\mathrm{N}$ in proteins and the $\mathrm{N}$ accumulates in the form of amines, amides and soluble amino acids (Epstein \& Bloom, 2006). Although the $\mathrm{S}$ concentrations in the $\mathrm{L}+1$ increased with the $\mathrm{N}$ rates from the ammonium chloride source (Figure 4d), there was a reduction in shoot production 120 d.a.f., possibly caused by the toxic effect of the $\mathrm{Cl}$ (Figure 2).

It is important to highlight that the leaf diagnosis analysis was undertaken to evaluate whether the plants were well-nourished or deficient in some element, but it was not possible to estimate crop nutrient extraction and accumulation. The nutrient dilution or concentration in $\mathrm{L}+1$ should therefore not be understood as lower or greater nutrient uptake, but rather whether the quantities absorbed are adequate and balanced with the others, which could be verified in the present study.

Stalk yield (MSS) and sugar production per hectare (MSH) in the final harvest were positively influenced by $\mathrm{N}$ increase (Figure $5 \mathrm{a}$ ). It is important to highlight that the salinity tolerance limit depends on the concentration and type of ion in solution, the time of exposure and developmental stage of the plants, of which the initial development phase is the most critical (Ayers \& Westcot, 1991). In spite of the increase in final yield, of around $14 \mathrm{Mg} \mathrm{ha}^{-1}$ of stalks, the possible toxic effect of $\mathrm{Cl}$ in the soil affected tillering directly (Figure 2) but not necessarily the final stalk weight. In addition, the sugarcane cultivar used (SP89 1115), known both for its high yield and excellent ratoon sprouting (even under straw), has potential for producing more than in this study $\left(115 \mathrm{Mg} \mathrm{ha}^{-1}\right)$ under more favorable conditions and was consequently limited by the toxic effect of the chloride ion, in spite of the yield increase.

The agricultural potential of use of ammonium chloride as $\mathrm{N}$ source was also shown by Barati et al. (2006) in field experiments with an irrigated rice crop in which ammonium chloride was applied at the doses of $0,50,100$ and $200 \mathrm{~kg} \mathrm{ha}^{-1} \mathrm{~N}$. The authors concluded that successive increases in $\mathrm{N}$ rates increased rice grain yield up to the dose of $100 \mathrm{~kg} \mathrm{ha}^{-1} \mathrm{~N}$. It must be emphasized, nevertheless, that in this case the irrigation water may have minimized the saline effect of the $\mathrm{Cl}$.

It is worth remembering that the concept of efficiency or of efficient $\mathrm{N}$ use may vary in accordance with the yield perspective; however, high efficiency must not be given priority over yield. It is known by the law of diminishing returns that with increasing $\mathrm{N}$ rates, yield increases are lower and, therefore, the efficiency reduced. In this same sense, despite the linear response of stalk and sugar yield to the application of $\mathrm{N}$, the increase was very low. The response in stalk yield starting from the yield of $90 \mathrm{Mg} \mathrm{ha}^{-1}$ (control), was only 5,11 and $16 \%$ for the doses of 60,120 and $180 \mathrm{~kg} \mathrm{ha}^{-1} \mathrm{~N}$, respectively. Under these conditions, the response in stalk and sugar production was not very significant from the economic point of view (Table 2). In the correlation analysis to verify the relationship between tillering 120 d.a.f. and the final stalk yield, the correlation (r) of this characteristics with stalk production per area was $0.64(\mathrm{p}<0.05)$.

In Brazil, Coelho et al. (2006) the agronomic efficiency in corn fertilized with ammonium chloride was greater than with urea and ammonium bicarbonate. The greater efficiency of $\mathrm{NH}_{4} \mathrm{Cl}$ was interpreted by the authors as due to the absence of $\mathrm{NH}_{3}$ volatilization in the soil, as occurred with the other amidic/ammonia fertilizers. In contrast, Barati et al. (2006), studying the effect of $\mathrm{N}$ sources (sulfurcoated urea, ammonium chloride and urea) on rice yield, concluded that grain yield was lower in the ammonium chloride treatment compared to the other sources.

Nitrogen fertilization of ratoon cane resulted in greater sugar production per hectare (Figure $5 b$ ) only in terms of yield increase, since there was no influence of the doses of ammonium chloride on any technical characteristic. The addition of $\mathrm{N}$ may increase sugar production per area; in other words, the sugar stalk content may even decrease with $\mathrm{N}$ fertilization; however the total quantity of sugars produced per hectare is greater as a result of greater yield in MSS (Korndörfer et al., 1997; Paes et al., 1997; Trivelin et al., 2002; Bologna-Campbell, 2007; Franco, 2008).
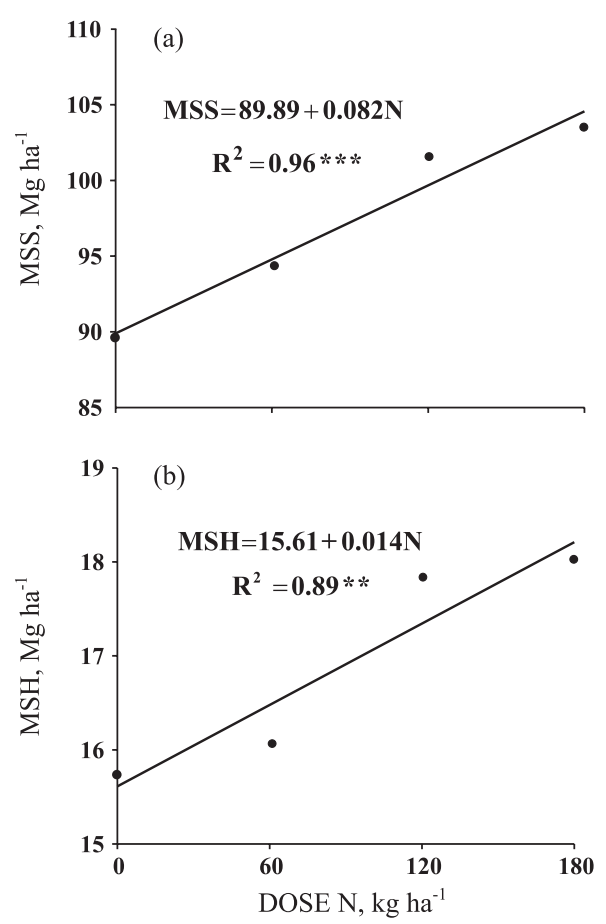

Figure 5. Stalk yield (MSS) (a) and sugar production per hectare (MSH) (b) in terms of doses of N$\mathrm{NH}_{4} \mathrm{Cl}$ (second ratoon of sugarcane). *** and *** significant at 1 and $5 \%$. 
It was observed that in the treatments with $\mathrm{NH}_{4} \mathrm{Cl}$, regardless of the dose applied, the ACM were lower than of the control. In spite of the yield stimulation of the second ratoon of sugarcane by the $\mathrm{NH}_{4} \mathrm{Cl}$ treatments, the gain in MSS was not sufficient to cover the cost of $\mathrm{N}$ fertilization (Table 2). The gain in yield from applying high $\mathrm{N}$ fertilizer rates was very low, only 2 tons, whereas the fertilizer cost was comparatively very high. Taking into consideration that the price of a ton of sugarcane stalks in the region is on average $R \$ 40.00 / t$, the increase of $R \$ 190.00 / t$ considering the difference of the dose of $120 \mathrm{~kg} \mathrm{ha}^{-1}$ compared to $180 \mathrm{~kg} \mathrm{ha}{ }^{-1} \mathrm{~N}-\mathrm{NH}_{4} \mathrm{Cl}$, would not pay for the yield gain.

\section{Residual-N of ammonium chloride- $\mathrm{N}$ in the third ratoon of sugarcane}

The $\mathrm{N}-\mathrm{NH}_{4} \mathrm{Cl}$ doses applied to the second ratoon (2006) did not alter the leaf concentration of macronutrients of the third ratoon of sugarcane (Table 3). With exception of the S leaf concentration, with values a little below the lower limit considered adequate for the state of São Paulo (1.5-3.0 $\left.\mathrm{g} \mathrm{kg}^{-1} \mathrm{DM}\right)$, the concentrations of the other nutrients were adequate and above average.

The increasing $\mathrm{N}-\mathrm{NH}_{4} \mathrm{Cl}$ doses applied in the 2006/ 2007 harvest resulted in a significant reduction in stalk production (MSS) in the 2007/2008 growing season. This effect was well-represented by the quadratic model (Figure 6a). This yield drop may be explained by the reduction in tillering in the previous cycle (Figure 2) due to the phytotoxic effect of the $\mathrm{Cl}$ in the soil, as already discussed, compromising sprouting and tillering of the second ratoon in the subsequent cycle and consequently the final stalk yield.

Due to the increased use of $\mathrm{KCl}$ fertilizer in most crops, the problem has been aggravated, which

Table 2. Agricultural contribution margin (ACM) in terms of nitrogen fertilization in the second ratoon cycle of sugarcane

\begin{tabular}{|c|c|c|c|c|c|c|c|c|}
\hline Dose N & MSS & TRS & Sugar & Gross Revenue & HLT Cost & Fertilizer Cost & Total Cost & $\mathbf{A C M}^{\#}$ \\
\hline $\mathrm{kg} \mathrm{ha}^{-1}$ & $\mathrm{Mg} \mathrm{ha}^{-1}$ & $\mathrm{~kg} \mathrm{t}^{-1}$ & $\mathrm{~kg} \mathrm{ha}^{-1}$ & & & US $\$ \mathrm{ha}^{-1}$ & & - \\
\hline 0 & 89.6 & 173.9 & $15,581.4$ & $2,444.9$ & 808.9 & 0.0 & 808.9 & $1,635.9$ \\
\hline 60 & 94.3 & 169.1 & $15,946.1$ & $2,502.2$ & 851.4 & 128.6 & 979.42 & $1,522.7$ \\
\hline 120 & 101.5 & 173.9 & $17,650.8$ & $2,769.7$ & 916.4 & 257.1 & $1,173.5$ & $1,596.1$ \\
\hline 180 & 103.5 & 172.9 & $17,895.1$ & $2,807.9$ & 934.5 & 385.7 & $1,320.2$ & $1,487.7$ \\
\hline \multicolumn{4}{|c|}{ Value $\mathrm{F}^{\#}=0.53^{\text {ns }}$} & $\mathrm{CV}(\%)^{\#}=11.7$ & & $\mathrm{MSD}^{\#}=580.4$ & & \\
\hline
\end{tabular}

NS: Non-significant, CV (\%):coefficient of variation, MSD: Minimum significant difference. MSS: tons of industrializable stalks per hectare; TRS: total recoverable sugar by ton of stalks; Sugar: MSS x TRS; Gross Revenue: Sugar x 0.2746 (average price of the TRS, March 2009); HLT: cost of harvest, loading and transport (HLT: R $\$ 15.80 \mathrm{t}^{-1}$ ) (average price of the Iracema Sugar Mill); HLT Cost: HLT (R\$) x MSS; Cost of fertilizer in March 2009: ammonium chloride: $\mathrm{R} \$ 937.5 \mathrm{t}^{-1}$ or $\mathrm{R} \$ 3.75 \mathrm{~kg}^{-1}$ of N. Total cost: HLT + fertilizer. ACM: Agricultural contribution margin; ACM: Gross revenue - Total cost. US\$1.00: R $\$ 1.75$ (November 2007 - closure of the 2006/2007 growing season).

Table 3. Concentration of macronutrients from the leaf diagnosis of sugarcane (third ratoon) 60 d.a.f. in relation to the doses of ammonium chloride- $\mathrm{N}$ applied on the second ratoon

\begin{tabular}{|c|c|c|c|c|c|c|}
\hline \multirow{2}{*}{ Dose N } & \multicolumn{6}{|c|}{ Adequate content for the São Paulo State ${ }^{(1)}$} \\
\hline & $\mathbf{N}$ & $\mathbf{P}$ & $\mathbf{K}$ & $\mathbf{C a}$ & Mg & $\mathbf{S}$ \\
\hline $\mathrm{kg} \mathrm{ha}^{-1}$ & $18.0-25.0$ & $1.5-3.0$ & $\begin{array}{r}10.0-16.0 \\
\text { Observec }\end{array}$ & $t^{2.0-8.0}$ & $1.0-3.0$ & $1.5-3.0$ \\
\hline 0 & 22.0 & 2.4 & 15.3 & 6.5 & 2.2 & 1.3 \\
\hline 60 & 20.5 & 2.5 & 16.8 & 5.3 & 2.2 & 1.4 \\
\hline 120 & 22.6 & 2.5 & 15.2 & 6.0 & 2.3 & 1.3 \\
\hline 180 & 21.8 & 2.5 & 15.4 & 6.6 & 2.2 & 1.3 \\
\hline $\begin{array}{l}F-L \cdot R \\
F-Q . R\end{array}$ & $\begin{array}{l}0.3^{\mathrm{NS}} \\
0.4^{\mathrm{NS}}\end{array}$ & $\begin{array}{l}1.6^{\mathrm{NS}} \\
2.0^{\mathrm{NS}}\end{array}$ & $\begin{array}{l}0.2^{\mathrm{NS}} \\
1.0^{\mathrm{NS}}\end{array}$ & $\begin{array}{l}0.7^{\mathrm{NS}} \\
2.4^{\mathrm{NS}}\end{array}$ & $\begin{array}{l}0.01^{\mathrm{NS}} \\
0.05^{\mathrm{NS}}\end{array}$ & $\begin{array}{l}0.01^{\mathrm{NS}} \\
0.2^{\mathrm{NS}}\end{array}$ \\
\hline CV (\%) & 3.5 & 4.5 & 8.7 & 19.4 & 11.4 & 14.2 \\
\hline
\end{tabular}

(1) Technical Bulletin 100 (Raij \& Cantarella, 1997); NS: not significant; L.R and Q.R: Linear Regression and Quadratic Regression, respectively. 

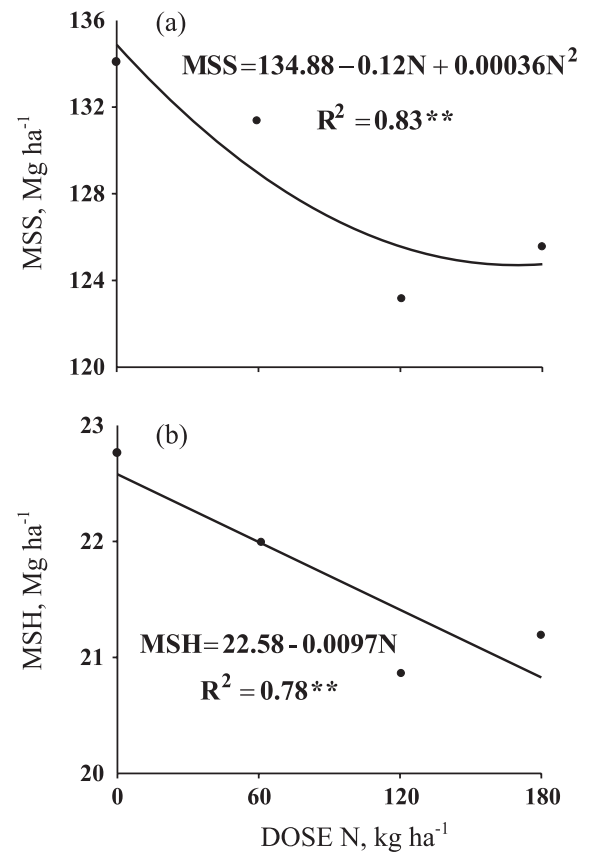

Figure 6. Stalk yield (a) and sucrose production (b) in terms of the residual effect of the doses of $\mathrm{N}$ $\mathrm{NH}_{4} \mathrm{Cl}$ (third ratoon of sugarcane). ** significant at $5 \%$.

consists of accumulation of $\mathrm{Cl}$ in plants, principally in perennial crops and in those whose crop residues return to the soil annually. Taking into consideration that $180 \mathrm{~kg}^{-1} \mathrm{~N}$ in the form of $\mathrm{NH}_{4} \mathrm{Cl}$ corresponded to approximately $554 \mathrm{~kg} \mathrm{ha}^{-1} \mathrm{Cl}$, as well as $120 \mathrm{~kg} \mathrm{ha}^{-1}$ $\mathrm{Cl}$ in the form of potassium chloride $\left(180 \mathrm{~kg} \mathrm{ha}^{-1} \mathrm{~K}_{2} \mathrm{O}\right)$, a reduction in yield may have occurred due to the toxic effect of residual $\mathrm{Cl}$, which reflected negatively on the productive potential of the crop at elevated soil concentrations.

As sugarcane is considered to be moderately sensitive to soil salinity (Santana et al., 2007), the decrease in yield may have been aggravated by the saline effect provoked by residual $\mathrm{Cl}$, keeping in mind that salt accumulation in the rhizosphere affects crop growth and development, provoking a yield decrease. This occurs due to the elevation of the osmotic potential of the soil solution by toxic effects of specific ions and alteration of the physical and chemical conditions of the soil (Fauconnier \& Bassereau, 1975; Maule et al., 2001).

On the other hand, Vitti et al. (2008) evaluating the efficiency of the ammonium chloride on wheat and barley, reported that results with this source, despite the high $\mathrm{Cl}$ content, were similar to those of urea. These facts call for further studies so that the response of $\mathrm{N}$ fertilization to ammonium chloride may be better understood, not only in one cycle, but with regard to the additive effect on consecutive cycles, since sugarcane is a semi-perennial crop.
Nitrogen fertilization with ammonium chloride of the second ratoon resulted in reduced sugar production per hectare of the subsequent cycle (Figure 6b) in terms of a reduced stalk yield only, since there was no influence of residual $\mathrm{N}$ from the ammonium chloride source on the sugarcane Pol content.

\section{CONCLUSIONS}

1. The application of $\mathrm{N}$ doses (60 to $180 \mathrm{~kg} \mathrm{ha}^{-1}$ ) in the form of ammonium chloride provided an increase in ratoon yield (second regrowth) of sugarcane. Nevertheless, the increases in crop yield represented no economic return, and the effect on the yield of the subsequent ratoon was negative (residual effect).

2. Since this is the first study on the use of ammonium chloride as alternative $\mathrm{N}$ source for sugarcane, further studies are required to deepen the understanding of this performance, mainly in relation to the quantity of $\mathrm{Cl}$ supplied and the possible damages (toxicity) to plants and to the environment.

\section{ACKNOWLEDGEMENTS}

The authors thank the National Council of Scientific and Technological Development (CNPq) for the scholarship, and the Sugar Mill Iracema and the Center of Sugar Cane Technology (CTC) for logistical support in the development of the project.

\section{LITERATURE CITED}

ASSOCIAÇÃO NACIONAL PARA DIFUSÃO DE ADUBOS . ANDA. Principais indicadores do setor de fertilizantes. Disponível em: <http://www.anda.org.br/estatisticas.aspx> Acesso em: Oct.26, 2009.

ASHRAF, M.Y.; ALVI, A.K.; SARWAR, G.; QURESHI, M.S.; ASHRAF, M. \& HUSSAIN, M. Effect of ammonium chloride on the growth and nutrient uptake by cotton grown in alkaline soil. Agrochimica, 49:153-164, 2005.

AYERS, R.S. \& WESTCOT, D.W. A qualidade da água na agricultura. Campina Grande, UFPB, 1991. 218p. (Estudos FAO. Irrigação e Drenagem, 29)

BAR-TAL, A.; FEIGENBAUM, S. \& SPARKS, D.L. Potassiumsalinity interactions in irrigated corn. Irrigation Science, 12:27-35, 1991.

BARATI, V.; EMAM. Y. \& MAFTOUN, M. Responses of two lowland rice cultivars to the different sources and levels of nitrogen. Agrochimica, 50:158-164, 2006.

BETHKE, P.C. \& DREW, M.C. Stomatal and non-stomatal components to inhibition of photosynthesis in leaves of Capsicum annuum during progressive exposure to $\mathrm{NaCl}$ salinity. Plant Physiol., 99:219-226, 1992. 
BLAIR, G.J.; MAMARIL, C.P. \& MILLER, M.H. Influence of nitrogen source on phosphorus uptake by corn from soils differing in pH. Agron. J., 63:235-238, 1971.

BOLOGNA-CAMPBELL, I. Balanço de nitrogênio e enxofre no sistema solo-cana-de-açúcar no ciclo de cana-planta. Piracicaba, Escola Superior de Agricultura "Luiz de Queiroz", 2007. 112 p. (Tese de Doutorado)

CANTARELLA, H. Nitrogênio. In: NOVAIS, R.F.; ALVAREZ V., H.V.; BARROS, N.F.; FONTES, R.L.F.; CANTARUTTI, R.B. \& NEVES, J.C.L., eds. Fertilidade do solo. Viçosa, MG, Sociedade Brasileira de Ciência do Solo, 2007. p.375470.

CLARKE, S.M. \& EATON-RYE, J.J. Amino acid deletions in loop $\mathrm{C}$ of the chlorophyll a-binding protein $\mathrm{CP} 47$ alter the chloride requirement and/or prevent the assembly of photosystem II. Plant Molec. Biol., 44:591-601, 2000.

COELHO, A.M.; RIBEIRO, B.N.; RESENDE, F.A. \& TEIXEIRA, Z.K. Eficiência agronômica do cloreto de amônio e do bicarbonato de amônio como fontes de nitrogênio para a cultura do milho. Sete Lagoas, Embrapa, 2006. 6p. (Comunicado Técnico, 136)

COSTA, M.C.G.; VITTI, G.C. \& CANTARELLA, H. Volatilização de $\mathrm{N}-\mathrm{NH}_{3}$ de fontes nitrogenadas em cana-de-açúcar colhida sem despalha a fogo. R. Bras. Ci. Solo, 27:631637, 2003.

EPSTEIN, E. \& BLOOM, A. Nutrição mineral de plantas: Princípios e perspectivas. 2.ed. Londrina, Planta, 2006. 403p.

FAUCONNIER, R. \& BASSEREAU, D. La caña de azúcar: Técnicas agrícolas y producciones tropicales. Barcelona, Blume, 1975. 433p.

FERNANDES, A.C. Cálculos na agroindústria de cana-deaçúcar. 2.ed. Piracicaba, STAB, 2003. 240p.

FRANCO, H.C.J.; TRIVELIN, P.C.O.; FARONI, C.E.F.; VITTI, A.C. \& OTTO, R. Aproveitamento pela cana-de-açúcar da adubação nitrogenada de plantio. R. Bras. Ci. Solo, $32: 2763-2770,2008$

FRANCO, H.C.J.; VITTI, A.C.; FARONI, C.E.; CANTARELLA H. \& TRIVELIN, P.C.O. Estoque de nutrientes em resíduos culturais incorporados ao solo na reforma do canavial. STAB - Açúcar, Álcool Subp., 25:32-36, 2007.

HARLING, H.; CZAJA, L.; SCHELL, J. \& WALDEN, R. A plant cation-chloride co-transporter promoting auxinindependent tobacco protoplast division, EMBO, 16:58555866, 1997.

JESCHKE, W.D.; ASLAM, Z. \& GREENWAY, H. Effects of $\mathrm{NaCl}$ on ion relations and carbohydrate status of roots and on osmotic regulation of roots and shoots of Atriplex amnicola. Plant Cell Environ., 9:559-569, 1986.

KORNDÖRFER, G.H.; VALLE, M.R.; MARTINS, M. \& TRIVELIN, P.C.O. Aproveitamento do nitrogênio da uréia pela cana-planta. R. Bras. Ci. Solo, 21:23-26, 1997.

LARCHER, W. Ecofisiologia vegetal. São Carlos, RiMa Artes e Textos, 2000. 531p.
MALAVOLTA, E.; VITTI, G.C. \& OLIVEIRA, S.A. Avaliação do estado nutricional de plantas. 2.ed. Piracicaba, Potafos, 1997. 319p.

MARSCHNER, H. Mineral nutrition of higher plants. London, Academic Press, 1995. 889p.

MAULE, R.F.; MAZZA, A.J. \& MARTHAR JÚNIOR, G.B Produtividade agrícola de cultivares de cana-de-açúcar em diferentes solos e épocas de colheita. Sci. Agríc., 58:295301, 2001.

PAES, J.M.V.; MARCIANO, N.; BRITO, C.H.; CARDOSO, A.A.; MARTINEZ, H.H.P. \& MENDES, A. Estudo de espaçamentos e doses de nitrogênio na produção e em algumas características biométricas de três variedades de cana-de-açúcar. STAB. Açúcar, Álcool Subpr., 15:1820, 1997.

RAIJ, B.van \& CANTARELLA, H. Outras culturas industriais. In: RAIJ, B.van; CANTARELLA, H.; QUAGGIO, J.A. \& FURLANI, A.M.C., eds. Recomendações de adubação e calagem para o Estado de São Paulo. Campinas, Fundação IAC, 1997. p. 233-243. (Boletim, 100)

ROLIM, G.S.; SENTELHAS, P.C. \& BARBIERI, V. Planilhas no ambiente EXCELTM para os cálculos de balanços hídricos: Normal, seqüencial, de cultura e de produtividade real e potencial. R. Bras. Agrometeorol., 6:133-137, 1998.

SANTANA, M.J.; CARVALHO, J.A.; SOUZA, K.J.; SOUSA, A.M.G.; VASCONCELOS, C.L. \& ANDRADE, L.A.B. Efeitos da salinidade da água de irrigação na brotação e desenvolvimento inicial da cana-de-açúcar (Saccharum spp) e em solos com diferentes níveis texturais. Ci. Agrotecnol., 31:1470-1476, 2007.

TAIZ, L. \& ZEIGER, E. Plant physiology. Sunderland, Sinauer Associates, 2004. 792p.

TISDALE, S.L.; NELSON, W.L. \& BEATON, J.D. Soil and fertilizer nitrogen. In: TISDALE, S.L.; NELSON, W.L. \& BEATON, J.D. Soil fertility and fertilizer. New York, Macmillan Publishing, 1985. p.112-188.

TRIVELIN, P.C.O.; VITTI, A.C.; OLIVEIRA, M.W.; GAVA, G.J.C. \& SARRIÉS, G.A. Utilização de nitrogênio e produtividade da cana-de-açúcar (cana-planta) em solo arenoso com incorporação de resíduos da cultura. R. Bras. Ci. Solo, 26:636-646, 2002.

TRIVELIN, P.C.O.; COLETI, J.T. \& LARA CABEZAS, W.A.R. Efeito residual na soqueira de cana-de-açúcar do nitrogênio da uréia aplicada por via foliar na cana-planta. In: SEMINÁRIO SOBRE TÉCNICAS NUCLEARES NA PRODUÇ̃̃O DE PLANTAS AGRÍCOLAS, 1984, Piracicaba. Anais... Piracicaba, CENA, 1984. p.119-124.

VITTI, A.C.; TRIVELIN, P.C.O.; GAVA, G.J.C.. PENATTI, C.P.; BOLOGNA, I.R.; FARONI, C.E. \& FRANCO, H.C.J.F. Produtividade da cana-de-açúcar relacionada ao nitrogênio residual da adubação e do sistema radicular. PAB, 42:249-256, 2007.

VITTI, G.C.; FARIA, M.R.M.; TOMASELLA, M. \& GRANDO, N. Fontes de nitrogênio aplicadas em cobertura, nas culturas do trigo e da cevada em dois tipos de solo. R. Agric., 83:197-207, 2008.

YAHYA, A. Salinity effects on growth and on uptake and distribution of sodium and some essential mineral nutrients in sesame. J. Plant Nutr., 21:1439-1451, 1998. 